\title{
The settling factors of Roman villas in southern Lusitania
}

\author{
Anett FIRNIGL \\ email: anett.firnigl@gmail.com \\ Corvinus University of Budapest, \\ Faculty of Landscape Architecture, \\ Department of Garden Art, \\ 29-43. Villányi Str., H-1118 Budapest
}

\begin{abstract}
The Romans arrived to the Iberian Peninsula in the $3^{\text {rd }}$ century B.C.: they transformed the Hispanian administration, the landscape and culture. The area of Lusitania expanded in the middle and southern part of Portugal, south from the River Douro, as well as on the autonom community of Extremadura, Spain. The production of the Roman villas gave the great mass the agricultural and commercial background of the Province. These produced wares got to the several lands of the Empire on the well-established road network and across the rivers and seas. The Roman villa was on a cultivation- and stock-raising-adapted farming unit with living houses, bath, and outbuildings, which had the biggest importance. The villas of Lusitania were concetrated into several groups: around the cities of Cascais and Lisboa, Évora and Mérida, as well. A bigger group ran along the southern coast of the Iberian Peninsula: the villas presented in this study (e.g., Milreu, Cerro da Vila, and Abicada) were specialized on seafood products and maritime trade. Other sites are also known where the presence of a villa has not been discovered yet, but where economic and industrial facilities were excavated (e.g., cetária, which means a basin for the production of the fish sauce garum in the Portuguese terminology).
\end{abstract}

Keywords: Iberian Peninsula, landscape, trade, pars urbana and rustica, villa maritima 


\section{Introduction. The appearance of the Romans on the Iberian Peninsula}

The first Roman army corps arrived at the Iberian Peninsula in 219 B.C. to wage war against the Carthaginians, who were recruiting Hispanian allies for the Second Punic War. The war ended with Roman victory: they extended their power almost on the whole peninsula, systematically occupying the area from south to north (Teichner 2005, Saraiva 2010). The Romans transformed the Hispanian administration, too: they organized the peninsula under two, later three provinces: Tarraconensis occupied the biggest area of the peninsula, Baetice was located on the southern edge and Lusitania along the Oceanus Atlanticus (Atlantic Ocean). Gallaecia was later separated from Tarraconensis at the north-western part of the peninsula and then Carthaginensis at the southern part at the end of the $3^{\text {rd }}$ century (see Figure 1).
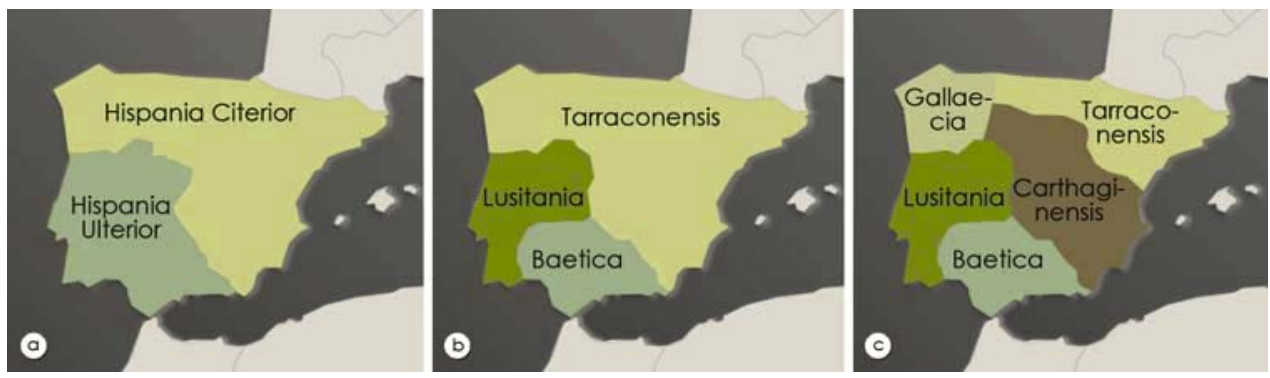

Figure 1: The administrative subdivision of Hispania in the Roman Age: in the Republic (a), in the Principate (b) and after Diocletian's reorganization in the 3rd century (c)

The area of Lusitania expanded in the middle and southern part of Portugal, south from the River Douro, as well as on the autonom community of Extremadura, Spain. In this study, those villas on the southern shore of Lusitania are presented which were specialized mainly on maritime trade.

\section{Materials and methods. The natural conditions and settlements of Lusitania}

The high level of industrial and agricultural production, the trade and financial systems, the advanced urban culture and the fine arts mean the culture of the Roman Empire. In addition, a key factor was the well-developed road 
network, the regular army, the written law and the Latin language. In the beginning, Lusitania had an importance for the Empire from a military point of view and it had a significant role in agricultural and handicraft production as well as in trading with Italy and other provinces (Saraiva 2010, Firnigl 2012, Moutinho Alarcão 1997). The Roman activity transformed the Hispanian landscape: they opened quarries and built military camps, cities with paved streets and villas from the excavated materials. These settlements were connected together with roads, which were sorrunded by cemeteries. The Romans exterminated forests, drained the moorlands and created ponds by building dams (Saraiva 2010, Firnigl 2012, Moutinho Alarcão 1997).

\section{The natural and climatic conditions of Lusitania}

The Tagus (today River Tejo) divided the area of the former Lusitania into two major areas and it was bordered by the Durius (today River Douro) on the north. The third major river of Lusitania was the Monda (today River Mondego), which flows through the city of Coimbra. The area bounded by the rivers Tagus and Durius is mountainous, including some parts of the Sierra de Estréla, the highest mountain in Central Portugal, reaching almost 2000 meters. The area south from the Tagus has plains and plateaus, and its coast has alternate rocky and sandy parts. The two regions of Southern Portugal are the Alentejo, with an approximated 400-m altitude, and Algarve at the southern coast, presented here in more details.

The raw materials of the quarries and mines with the workshops were one of the most important economic factors of Roman Portugal, especially in the northern areas (Edmondson 1989, Moutinho Alarcão 1997). The number of mines in the southern parts is lower; there are only seven sites in the municipalities examined here (there are four mines in the municipality of Silves, mainly copper mines, two in Loulé, and only one in Albufeira): these mines are in the ca. 200-250-m high regions (Marques 1992; see Figure 2).

Today, the climate of the coast in Southern Lusitania is Mediterranean, where the annual mean temperature is $18^{\circ} \mathrm{C}$. South from the Tejo, the annual rainfall is $500-700 \mathrm{~mm}$ and in Algarve it is only ca. $450 \mathrm{~mm}$. The continental type of the climate is stronger from the coasts towards the middle of the country; rainfall highly increases in the northernmost parts. The Roman dams were built where the average annual rainfall was relatively low: most of the dams were in the areas under ca. $800 \mathrm{~mm}$ rain and under ca. $600 \mathrm{~mm}$ at Southern Portugal (Butzer et al. 1985, Marques 1992, Moutinho Alarcão 1997). The water storage capacity of streams swollen by the dams reached 
several hundred thousand cubic meters: the dam of Lameira (Vila Velha da Ródão) kept 840,000 $\mathrm{m}^{3}$ of water (Moutinho Alarcão 1997).

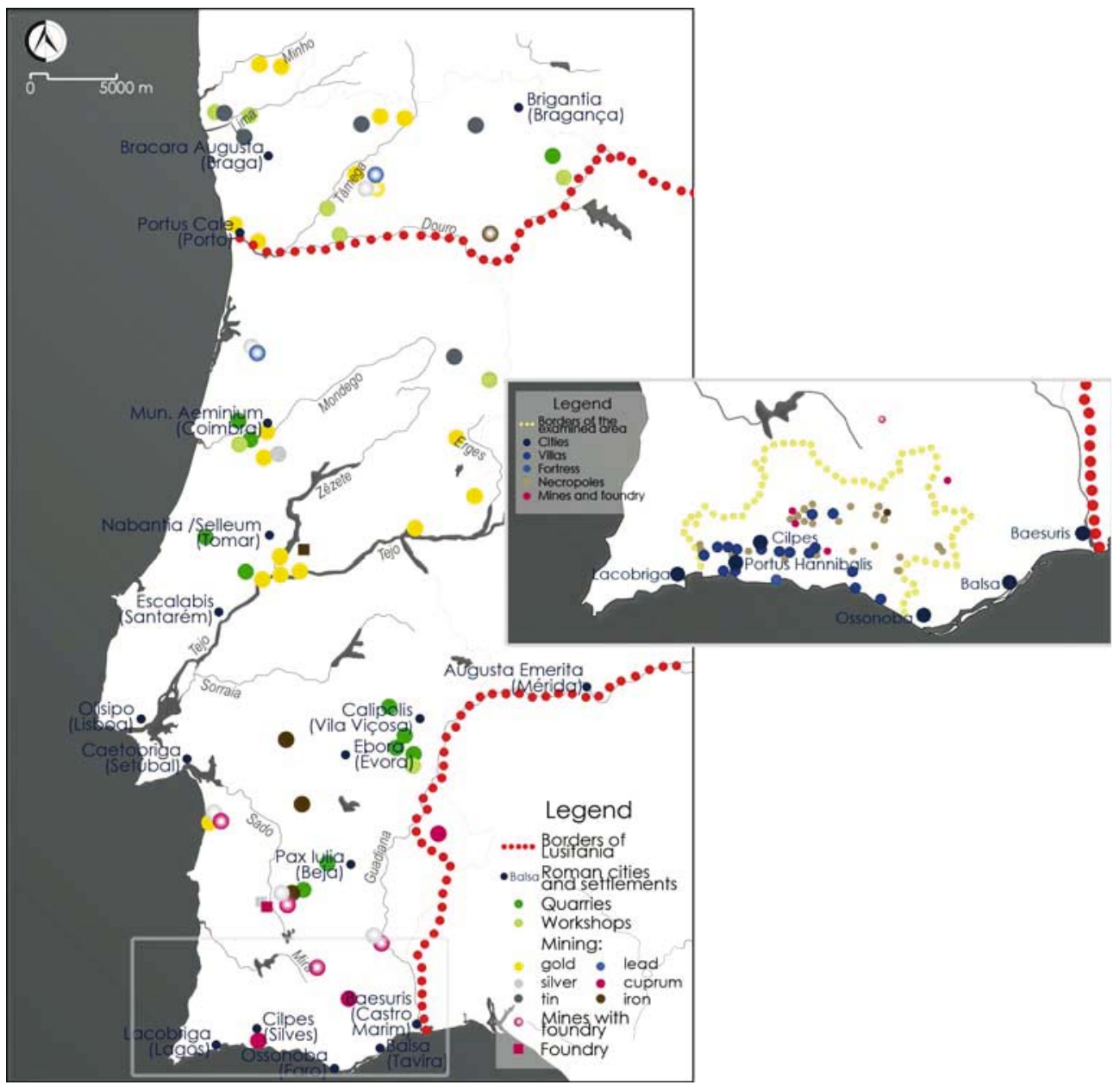

Figure 2: The mines and quarries of Roman Portugal, with the details of the examined area (after Marques 1992 and Moutinho Alarcão 1997, p. 80. and p. 96.)

The dams were also connected to the villas: the Romans covered the water from the swollen waters for the irrigation of gardens and fields, for watering animals and for the water supply of baths as well (Firnigl 2012, Moutinho Alarcão 1997; see Figure 3). 


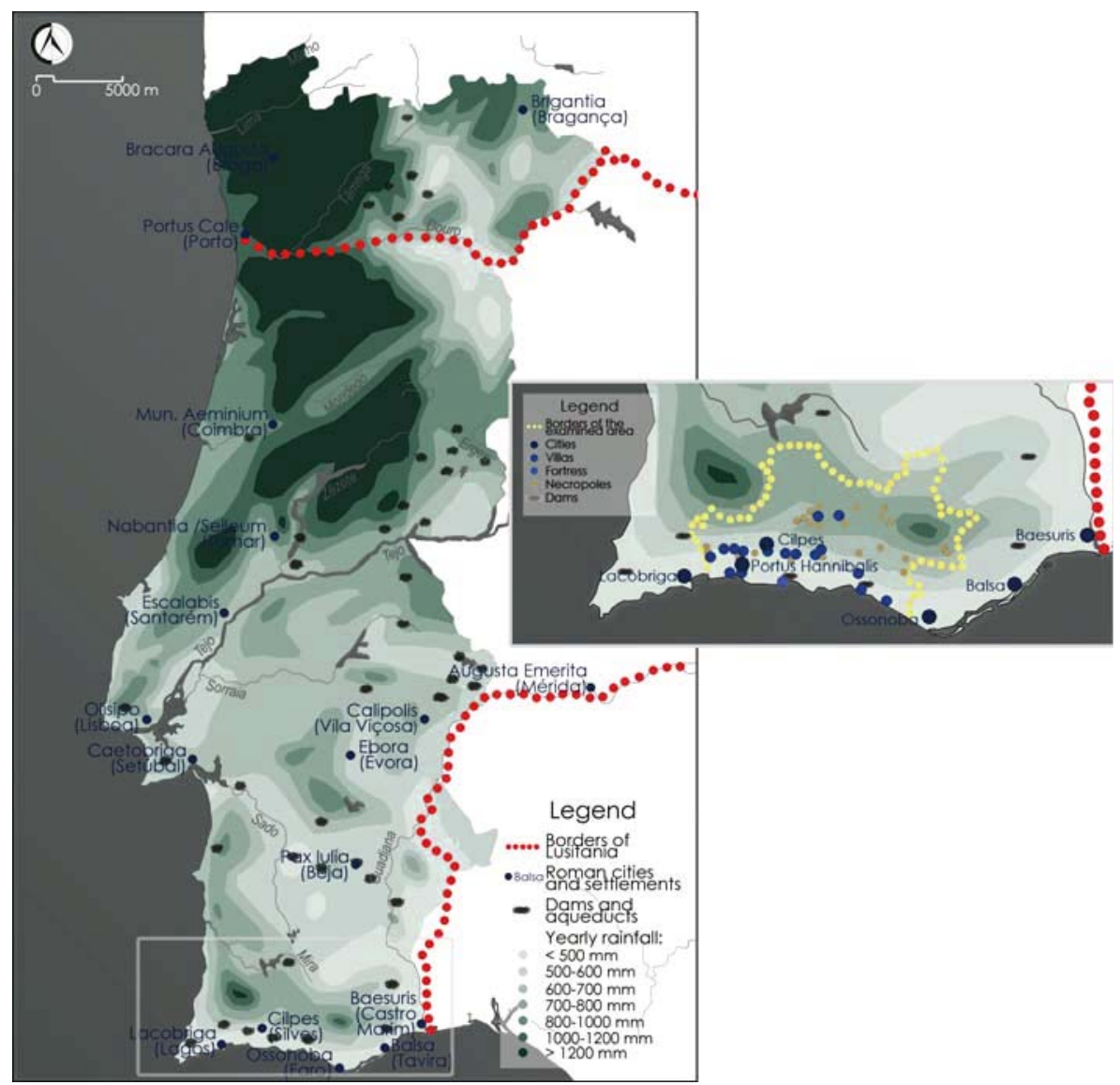

Figure 3: The dams and aqueducts of Roman Portugal with the details of the examined area (after Marques 1992 and Moutinho Alarcão 1997, p. 18.)

\section{The settlement network of Lusitania}

According to Pliny's description in the $1^{\text {st }}$ century, Lusitania was fragmented into three so-called conventus (Roman judicial and administrative units): their centres were Augusta Emerita (today Mérida, Spain), Pax Iulia (today Beja, Portugal) and Escalabis (today Santarém, Portugal). A total of 45 urban settlements were created here (Saraiva 2010), which were linked with a welldeveloped road network (Thompson 1918). The directions of the main roads are still identifiable: these roads facilitated the freight transport and several bridges were maintained over the streams (Marques 1992, Saraiva 2010; see Figure 4). 


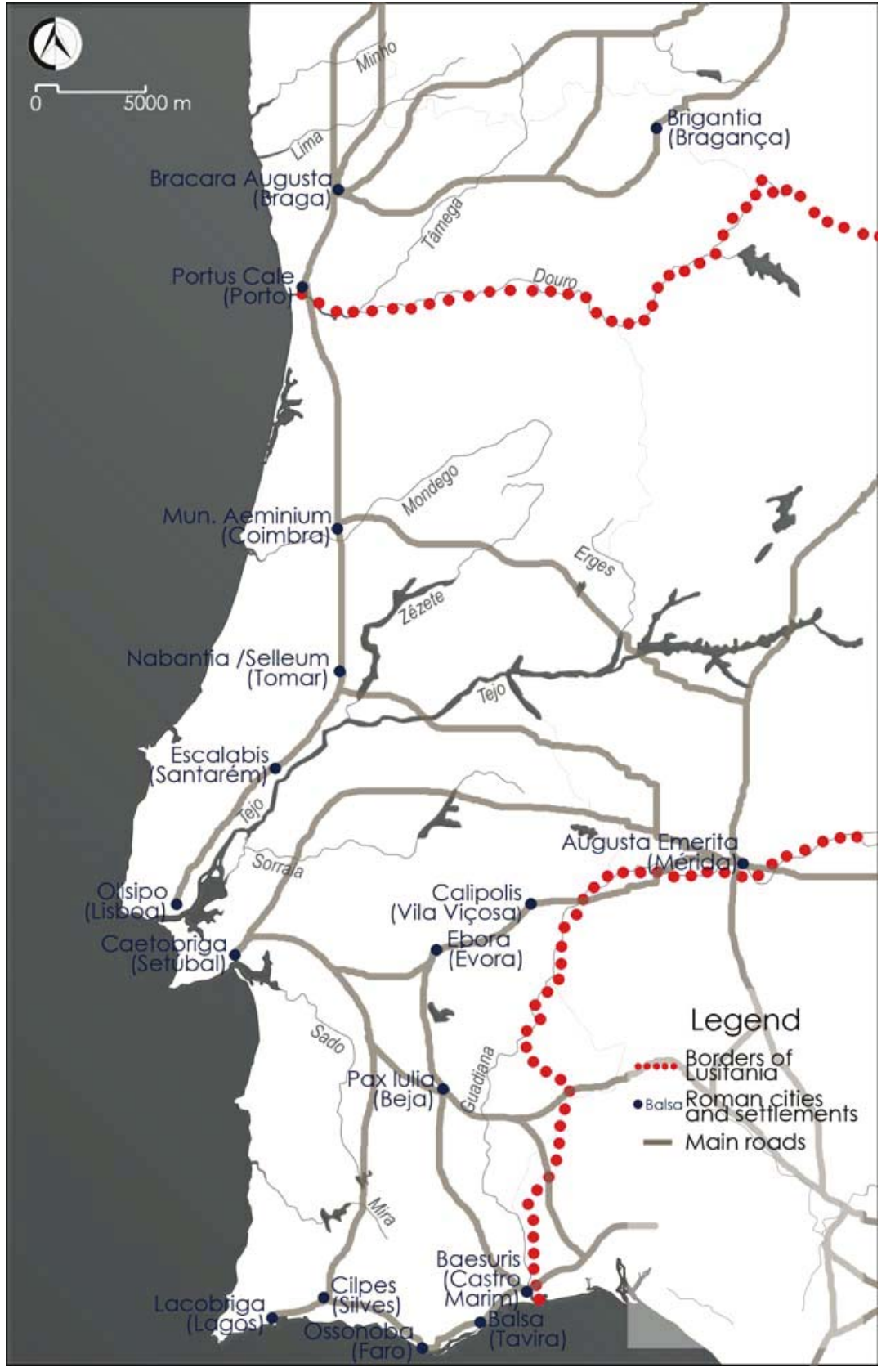

Figure 4: The main roads of Roman Portugal 
Olisipo (today Lisboa, the capital of Portugal) grew into a large port city at the beginning of the period of the Roman Empire: it was a node from where the local products were transported to Italy. The culitvation of cereals contributed to the development of the towns of Roman origins, Santarém, Évora, Beja and Alcácer do Sal as well (Saraiva 2010). The most important towns and settlements on the southern shore were Balsa (today Tavira), the port city of Ossonoba (today Faro) and Cilpes (today Silves), Lacobriga (Lagos), Baesuris (Castro Marim), Portus Hannibalis (vicinity of Portimão), Ipses (Alvor) and also Conistorgis (unknown place). Many villas were established in the districts of these towns: 18 villas and seven rural settlements can be identified on the southern coast, examined here. Besides them, three other sites can be determined as villas, where only economic or agricultural buildings (e.g., silo, press house) were found. A fortress is also known on the southern coast, as well as 27 cemeteries or graves, where the connected settlements are not known yet (Marques 1992, Teichner 2005).

\section{The meaning of 'villa' and the Lusitanian villas}

The word villa is a generic term without architectural meaning originally (see B. Thomas 1961, Mócsy and Fitz 1990, Marzano 2007, Moutinho Alarcão 1997): it does not mean holiday house in the modern sense, but a farming unit producing for the local market, with residential houses, outbuildings (e.g., barns, stables, sheds) and gardens (vegetable garden, orchards and flower gardens). These units were distinguished (see B. Thomas 1961, Mócsy and Fitz 1990) with the names pars urbana (the residential part with the owner's or tenant's main building and baths) and pars rustica (with two or more outbuildings). The pars rustica had significance originally: Cato explained all of its elements, but he noted about the villa urbana that it had to be constructed according to the owner's financial opportunities (villam urbanam pro copia aedificat; see Mócsy and Fitz 1990). The focus was on the production in Italy and especially in the provinces, which took place in the villas.

The centres of the farms were usually enclosed with wooden or stone walls (Mócsy 1995), but they were not primarily built for defensive purposes: these walls were built as fences to indicate the boundaries of the manor, separating the fields and pastures from the pars urbana and rustica, to hold the crops, tools and animals in the central yard (K. Palágyi 1994, Mócsy 1995). Fields belonged to the villas in the original meaning, even so closely that a parcel could have the name fundus only in the case when a villa stood on it (Mócsy and Fitz 1990). The quantity and quality of buildings, the size of the main 
building and the fenced central yard probably refer to the size of the property: the auctors' requirement was that the villa had to be proportional with the size of the fundus. According to this, small (2.5-50 acres area), medium-sized (20-125 acres) and large (over 125 acres) estates can be distinguished (see Hainz Dohr's estate categories, White 1966). The size of the estates could depend on the location inside the province, on natural and terrain conditions, and on the production methods as well.

The examination of Hispanian villas is thourough, especially in the Spanish areas, but the researches in Portugal are in disatvantage: Jean-Gérard Gorges's inventory is the most detailed work from 1979 on; however, he rather specialized in Spanish sites. The archaeological-topographical series is the most recent summary, edited by Teresa Marques. The villas of Lusitania were concetrated in several groups: the first major group is observed around the cities of Cascais and Lisboa; furthermore, several villas surround Évora and Mérida as well. A bigger group runs through the southern coast of the Iberian Peninsula: these villas were specialized in seafood products and maritime trade. The typical territory of the estates is around 200 acres (large estates) at the Alentejo, but only 20-50 acres (medium-sized estates) in the Northern Lusitania (Saraiva 2010. Moutinho Alarcão 1997). This north-south difference still remained at the beginning of the $20^{\text {th }}$ century, too (Thompson 1918).

The meaning of the villa changed later, to the late Imperium (B. Thomas 1961, Mócsy and Fitz 1990); various terms were separated by the function and location of villas. Thus, the so-called refugium villas were built for defense against the barbarian attacks. The villa publica was a wayside buy-in restaurant, a station for log change (mutatio). The villa suburbana was independent from the fields; it is the collective name of peri-urban luxury homes built for vacation (this word is the ancestor of the modern villa concept). The villa pseudourbana had an estate, but the closed, inward-looking main building was built after the model of urban residences (B. Thomas 1961, Castiglione 1971, 1973, McKay 1980, Vitruvius 1988). The villa maritima has to be mentioned here, which, contrary to the villa rustica, was a rich building with an opened front to the seas, appearing also in Lusitania (Marzano 2007).

The villas were typically Roman units, so they are not known from preRoman times (B. Thomas 1961). Only the Romans and veterans were living in this architectural unit initially, then also the natives got more and more fields with the romanization (B. Thomas 1961). The constructions of the ancient Romans followed simplicity plans, the settlements and buildings were established in the provinces by basic types modelled in Italy (Mócsy 1974, Mócsy and Fitz 1990). These schemes can be discovered at the domus, too; 
the Roman houses were built on the same type, which were modified mostly according to the local climate. These types of houses were taken over for construction of villas as well. Two main types can be distinguished with the layout of main residential buildings, although these types appeared clearly rarely. The rooms of porticus villas or villas with central corridors were organized in linear order, and they had usually smaller areas. The villas with peristylium or with central patio had bigger areas (B. Thomas 1961, Mócsy and Fitz 1990, Reutti 1994, Bechert 2005): in the following examined villas, mostly this type of patio can be found.

The German terminology uses two words to differenciate the location of living houses and outbuildings inside the fenced courtyard (Reutti 1994). The Axial-typ or Achsenhof means the regular order, the axial classification of farm buildings. In the case of the so-called Streuhof-typ, the buildings are placed scattered, without any geometric order in the yard. These categories can not be applied on the villas of Southern Lusitania based on our present knowledge. However, the encircling walls, the fences can be found with some villas, clearly separating the pars urbana and pars rustica from each other.

Probably, ornamental gardens belonged to the pars urbana, too; the roots of them go back to the cities, like at the scheme of domus (Castiglione 1971, 1973, 1979, Jashemski 1979). The urban gardens (hortus, viridarium) were small, apart from a few rich examples, and they had decorative functions primarily, with useful spices and herbs as well. The appearance of aqueducts in houses caused changes in the equipment of the reception rooms (atrium) and inner gardens (peristylium): the rainwater catchment basins were replaced by marble, with fountains and statues decorating the basins. The excavated houses of the Roman town Conimbriga show the varied formations of these pools. The water arrived to the city in well-built aqueducts and it had a large-scale use: e.g., as the water of geometric pool-systems with planting islands; the small fountains had favourable effect on the climate (Alarcão 2000, Correia 2008, Moutinho Alarcão 1997). Dining spaces were often placed in the gardens, too; a triclinium was excavated in the garden of the villa at Cerro da Vila (Marques 1992).

\section{The economic life and agriculture of Lusitania}

The Celts started to use more advanced agricultural and cultivation techniques than the natives had then in Portugal. The population living here was extremely complex at the beginning of the Roman conquest, but the Roman colonization reduced the ethnic differences of the peninsula. The 
Romans recognized the countryside, the natural features during the wars against Carthage, and they used these potentials after the conquest of this area (Saraiva 2010). Wheat, grape and olive were the most suitable for the local climate and soil conditions. The production of these plants came on such an advanced level with the involvement of the labour of indigenous people in the Roman period that the products could be exported, too (Thompson 1918, Saraiva 2010).

The first villas were owned by veterans and Italian immigrants initially, and they built on the most fertile areas: these fields were made productive with slave labour. The Roman plough replaced the previuos one south from the Tagus; however, the natives retain their tools in the north (Saraiva 2010). The process of development of the Hispanian agriculture and the exploitation of marine resources started at the foundation of Lusitania province, and it peaked in a few decades. The centres of this process were the villas presented here (e.g., Abicada, Cerro da Vila): these farms followed each other along the coast. The first villa foundations in Southern Lusitania started in the second half of the $1^{\text {st }}$ century. The new constructions, alterations and technical ameliorations reflect the continuous development and growing wealth in the second half of the $3^{\text {rd }}$ century; they are the witnesses of the expansion of production capacity and the economic success of the owners. Inter alia, the oil presses in Milreu and the large workshop in Cerro da Vila were established at that time (Teichner 2005, Moutinho Alarcão 1997). The economic crisis striking the Empire in the $3^{\text {rd }}$ century did not reflect its impact in Southern Lusitania: abandoning some of the villas located here was caused rather by natural events (for example, a big flood at Cerro da Vila; see Teichner 2005).

\section{Results and discussions. The villas of southern Lusi- tania (Algarve)}

Becoming acquainted with Roman agriculture is essential to the examination of the regional and cultural context of the villas. The works of the ancient authors (auctor), the wall paintings and mosaic pavements (on Lusitanian mosaics, see Oliveira 2010) as well as the fine arts provide a picture of the country life and agriculture. Besides these, the aerial photographs can also show possession structures and cultivation forms in rare cases.

The most prominent agricultural authors were Cato, Varro, Columella, Pliny the Elder and Pliny the Younger, and Palladius: they wrote about the estates, cultivation and management forms and processes, about the cultivated plant 
species and tools as well. The ancient authors gave useful pieces of advice for the owners of the farms: they wrote about the selection of the right location for building a villa, about the right placement of living houses and outbuildings on the farms. It was beneficial for the villa if it had a water source inside of the fenced area or nearby the farm, if it had a good kitchen and a cellar according to the size of the estate. Cato emphasized the observation of the neighbours' welfare connected to the aspects of purchasing an estate: the climate is certainly favourable and the soil is good if the neighbours live well (Cato I. 2.). The most important aspects for an ideal estate are: "if possible, it should lie at the foot of a mountain and face south; the situation should be healthful, there should be a good supply of labourers, it should be well watered, and near it there should be a flourishing town, or the sea, or a navigable stream, or a good and much travelled road" (Cato I. 3.). The size of the ideal estate is of 100 iugerum (about 25 acres; see Heimberg 1977). Cato emphasized the importance of a well-built pars rustica: oil and/or wine cellars (cella olearia and cella vinaria) with barrels and runlets (dolia) and good presses (torcularia) included into the equipment of estates, in addition to the buildings.

Varro's opinion was that the aim of agriculture is the pursuit of profit and pleasure (ad utilitatem et voluptatem). However, he emphasized the importance of the beauty of the land and estate, which is advantageous at sale (Varro 1.4.1-2.). A farm is profitable when the costs of transportation of the produced goods are favourable and if the delivery of the materials needed by the villa is low-cost (Varro 1.16.3): "if there are towns or villages in the neighbourhood, or even well-furnished lands and farmsteads of rich owners, from which you can purchase at a reasonable price what you need for the farm, and to which you can sell your surplus, such as props, or poles, or reeds, the farm will be more profitable than if they must be fetched from a distance; sometimes, in fact, more so than if you can supply them yourself by raising them on your own place." Nevertheless, high-quality roads and navigable rivers for the transport of the products have to be available as well (Varro 1.16.6). In Columella's opinion, the mixed intensive farming was the best form of cultivation and management, where the cereal, the olive trees and vineyards, the livestock and grazing are in about same proportions.

The cultivation of grapes and olives, the production of wine and oil were the most profitable sectors in the Roman agriculture. The authors had divided opinions about the ideal orientation of the vineyards (vinea): Virgil suggested western, Columella eastern or southern aspects, but the most appropriate place has to be experienced in Pliny's point of view, the selection of the ideal area 
depends on the location and the potential of the possession (Firnigl 2012). The climate of Lusitania was perfect for cultivating olives and especially grapes, as mentioned above.

Nearly $40 \%$ of Hispanian villas were built on alluvial soils, what is particularly favourable for wheat cultivation, stock-raising and home gardens: this is mainly due the fact that the alluvial soils are along the rivers, and the Romans settled close to the rivers (see Gorges 1979, Edmondson 1981). Portugal is primarily an agricultural country, three-quarters of its area is fertile (onethird of it is arable land and one-third is covered with forests and wooded areas; this remained also in the $20^{\text {th }}$ century; see Thompson 1918). However, the maritime trade had primary importance in Southern Lusitania (Teichner 2004).

The determined villas in five municipalities (concelho) of the region Algarve are examined here, dealing especially with the excavated sites. Six villas are identified in Portimão (e.g., Bairro da Boavista, Abicada), five in Loulé (for example, Milreu, Cerro da Vila), one in Lagoa, six in Silves, while Roman villas are not known in Albufeira (Figure 5).

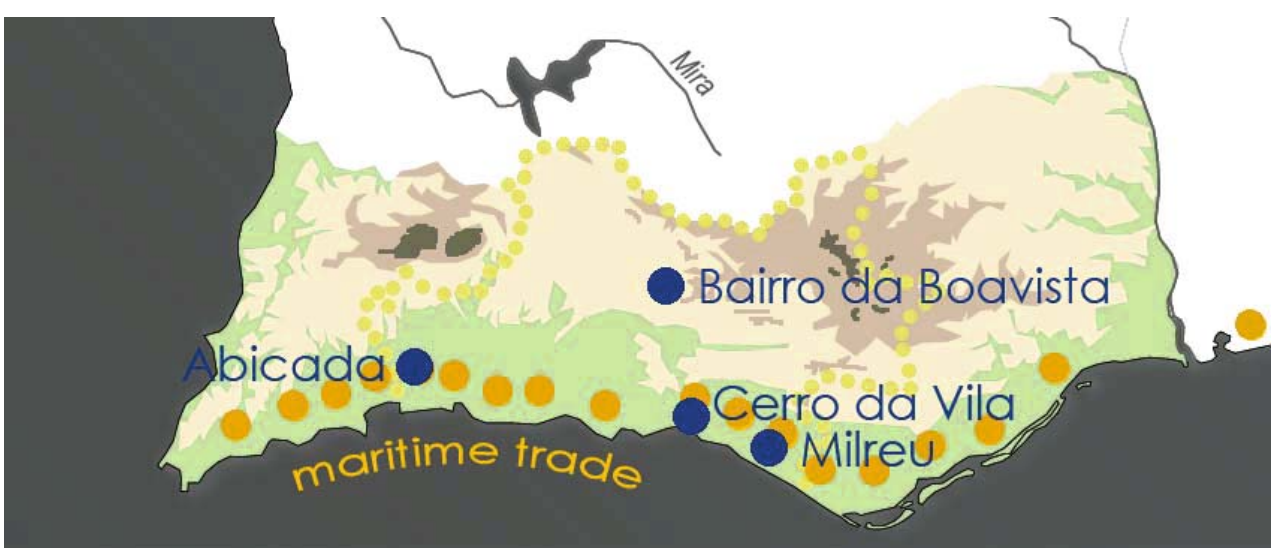

Figure 5: The presented villas of Southern Lusitania with other settlements, necropolis and the sites of maritime trade (after Marques 1992 and Moutinho Alarcão 1997, p. 39.)

The main building of the villa of Bairro da Boavista (Portimão) has mosaic pavement and it is located approximately $500 \mathrm{~m}$ far from the River Barranco do Poco. A mill and a large twin-tank are known in its pars rustica (Marques 1992, Moutinho Alarcão 1997). The villa of Abicada (Mexilhoeira Grande) was lay close to the ancient port city of Portus Hannibalis: its area is ca. 
$250 \mathrm{~m}$ far from the mouth of two rivers, exposed to the Atlantic winds. The main building of the pars urbana was made on the classical scheme of villa maritime, probably in the $2^{\text {nd }}-3^{\text {rd }}$ centuries. So far, little information is available about the pars rustica: fishery products (for instance, garum, one of the main materials of Roman cuisine; see Apicius 1996) were prepared here (Marques 1992, Keay 2003, Teichner 2005).

The villa of Milreu (Estoi) was built in the hinterland of the port city of Ossonoba, beside the Faro-Beja road, on a western slope at Rio Seco (Figure 4). The villa has an antecedent from the early Empire, which was rebuilt as a centre of a large estate at the end of the $1^{\text {st }}$ century. A rich main building with mosaic pavement and large central courtyard (peristylium), and a bath (balnea) were in the pars urbana. Workshops, mills, water reservoirs and halls - probably for the large-scale production of olive oil and wine - were built in the pars rustica. In addition, two mausoleums and a cult building from the $4^{\text {th }}$ century (nymphaeum) are also known here, which remained in use even after the Roman era (Teichner 2005).

The villa of Cerro da Vila (Quarteira) was built approximately $12 \mathrm{~km}$ westnorthwest from Osoonoba. A bay was here in the Roman period: this natural harbour was favourable for the settling (the siltation of the northwestern part of this bay and the isolation from the ocean caused the depopulation of many surrounding settlements and villas, including Marmeleiros from the 1st century, neighbouring Cerro da Vila; see Marques 1992, Teichner 2005). The proximity of the ocean (fishing and maritime trade) gave the richness of Cerro da Vila and its continuous development. The settling time of the villa is probably the first half of the $1^{\text {st }}$ century, thanks to the territorial reorganization related to Augustus's province establishment. A main building with peristylium and thermae stood in the centre of the pars urbana. The regulated water supply was solved at high costs: the water was led from the dam of Vale de Tesnado from $1600 \mathrm{~m}$ distance (Moutinho Alarcão 1997 and see Figure 3). The water was essential for the factories for seafood products in the pars rustica (fabricae, the factories at Cerro da Vila - from the beginning of the $2^{\text {nd }}$ century - were the biggest commercial facilities of Lusitania known today), and for a therma. Several residential buildings are also known in the pars rustica, what indicates a large number of workers. Two mausoleums and a necropolis belonged to the villa as well (Marques 1992, Teichner 2005).

Streams or smaller rivers pass through the 150-500 m large environment at all of the 18 examined villas. These settlements were built in the lowest elevation zones, at the average height of 50-100 m, mostly on southern or western slopes (none of the villas are situated over $400 \mathrm{~m}$ height; this feature 
can be found in other provinces, too, e.g., in Dacia and Pannonia; see Wanner 2010, Firnigl 2012).

\section{Conclusions}

The Romans fell into deep economic crisis at the beginning of the $5^{\text {th }}$ century. Their political and administrative system was torn apart by the barbarian tribes invading from Eastern Europe: neither the Romans nor the Roman-ally Visigoths were able to repel the attack of the Alans, Vandals and Suebis. The shortage of slaves, the basics of economy, and the stagnant export, then the expansion of the barbarian tribes led to the final decline and disintegration of the province (Saraiva 2010). However, the villa system survived, several buildings were inhabited even in the $8^{\text {th }}$ century and in the Islamic period, and the characteristic size of estates was clearly visible in the $20^{\text {th }}$ century, too.

\section{References}

[1] Alarcão, J. de (1988), Roman Portugal. Aris \& Phillips, Warminster.

[2] Apicius, M. G. (1996), Szakácskönyv a római korból [De re coquinaria]. Enciklopédia Kiadó, Budapest.

[3] B. Thomas, E. (1961), Rómaikori villák a Balatonvidéken [Roman Villas on the Balaton Highland]. Képzőmüvészeti Alap Kiadóvállalata, Budapest.

[4] Bechert, T. (2005), Hof oder Halle? Anmerkungen zur Überdachung des zentralen Innenbereichs kaiserzeitlicher Risalitvillen. Balácai Közlemények IX.: 165-176.

[5] Butzer, K. W. et al. (1985), Irrigation Agrosystems in Eastern Spain: Roman or Islamic Origins? Annals of the Association of American Geographers 75/4: 479-509.

[6] Castiglione L. (1971), Római művészet [Roman Art]. Corvina, Budapest.

[7] Castiglione L. (1973), Pompeji. Corvina, Budapest.

[8] Castiglione L. (1979), Pompeji. Herculaneum. Gondolat KönyvkiadóMagyar Helikon Könyvkiadó, Budapest. 
[9] Cato (2003) De agri cultura In: Borhy, L. (ed.): Római történelem. Szöveggyüjtemény. Osiris Kiadó Kft., Budapest

[10] Edmondson, J. C. (1981), Review - Gorges, J.-G.: Les Villas HispanoRomaines: Inventaire et Problématique Archéologiques/Paris, 1979/. The Journal of Roman Studies 71: 217-218.

[11] Edmondson, J. C. (1989), Mining in the Later Roman Empire and beyond: Continuity or Disruption? The Journal of Roman Studies 79: 84-102.

[12] Firnigl, A. (2012), Római kori villák történeti környezetének vizsgálata a Balaton-felvidéken [The Examination of the Historical Environment of Roman Villas on the Balaton Highland]. PhD Dissertation, typescript, Corvinus University of Budapest.

[13] Gorges, J-G. (1979), Les Villas Hispano-Romaines. Inventaire et problématique archéologiques E. de Boccard, Paris.

[14] Heimberg, U. (1977), Römische Landvermessung. Gesellschaft für Vorund Frühgeschichte in Württemberg und Hohenzollern, Stuttgart.

[15] Jashemski, W. F. (1979), The Gardens of Pompeii, Herculaneum and the Villas destroyed by Vesuvius. Caratzas Brothers, New Rochelle.

[16] K. Palágyi, S. (1994), Őskor, római kor, népvándorlás kora. In: Veress D., Cs. (ed.): Nemesvámos története - A község története az ősidőktől napjainkig [History of Nemesvámos from the ancient times to the present days]. Gubicza Ferenc, Veszprém, pp. 7-47.

[17] Keay, S. (2003), Recent Archaeological Work in Roman Iberia (19902002). The Journal of Roman Studies 93: 146-211.

[18] Marques, T. (ed.) (1992), Carta arqueológica de Portugal: Concelhos de Portmao, Lagoa, Albufeira, Loulé e Sao Bras de Alportel. IPPAR, Lisboa.

[19] Marzano, A. (2007), Roman Villas in Central Italy. A Social and Economic History. Columbia Studies in the Classical Tradition, vol. 30.

[20] McKay, A. G. (1980), Römische Häuser und Paläste. Raggi Verlag, Feldmeilen. 
[21] Moutinho Alarcão, A. (ed.) (1997), Portugal Romano: A exploraçao dos recursos naturais. S. n., s. l.

[22] Mócsy, A. (1974), Pannonia a korai császárság korában [Pannonia in the early Roman Empire]. Akadémiai Kiadó, Budapest.

[23] Mócsy, A., Fitz, J. (eds.) (1990), Pannonia régészeti kézikönyve [Archaeological Guide of Pannonia]. Akadémiai Kiadó, Budapest.

[24] Mócsy, A. (1995), Pannonia városai, falvai és villái a II. század közepén. In: Stirling, J. (ed.): Szöveggyüjtemény a kertépítészet történetének tanulmányozásához - I. Klasszikus ókor, I.1. Róma. Kertészeti és Élelmiszeripari Egyetem, Budapest, pp. 157-161.

[25] Oliveira, C. Fernandes de (2010), Mosaicos romanos de Portugalo o Algarve oriental. PhD Dissertation, Coimbra.

[26] Reutti, F. (1994), Typologie der Grundrisse römischer Villen. Balácai Közlemények III.: 200-205.

[27] Saraiva, J. H. (2010), Portugália rövid története [Short History of Portugal]. Equinter, Budapest.

[28] Teichner, F. (2004), Purpur, Olivenül und Fischsaucen als Exportartikel. Wirtschaftsarchäologische Untersuchungen am.

[29] Teichner, F. (2005), Neue Forschungen zur Ländlichen Besiedlung im Süden der römischen Provinz Lusitanien. Balácai Közlemények IX.: 117132.

[30] Thompson, W. (1918), Portugal: The Country and the People. Geographical Review 6/2: 147-155.

[31] Varro (2003) Rerum rusticarum libri tres. In: Borhy, L. (ed.): Római történelem. Szöveggyüjtemény. Osiris Kiadó Kft., Budapest and after www.rbedrosian.com

[32] Vitruvius (1988), Tíz könyv az építészetről [De architectura]. Képzőmüvészeti Kiadó, Budapest.

[33] Wanner, R. (2010), Forts, fields and towns: Communities in Northwest Transylvania from the first century BC to the fifth century AD. PhD Dissertation, typescript, University of Leicester.

[34] White, K. D. (1966), H. Dohr, Die italischen Gutshöfe nach den Schriften Catos und Varros. Review. The Journal of Roman Studies 56: 249-250. 